\title{
Reflection on the Social and Psychological Consequences of the Coronavirus Pandemic in the New Vocabulary of the Non-professional English Language Medical Discourse
}

\author{
Katermina V.V. ${ }^{*}$ Lipiridi S.Ch.
}

\author{
Kuban State University, Krasnodar, Russia \\ *Corresponding author. E-maill: katermina_v@mail.ru
}

\begin{abstract}
The article is concerned with neologisms of non-professional English language medical discourse, devoted to the social and psychological consequences of the coronavirus pandemic. It analyzes the reflection in the new medical vocabulary of such social realities created by the pandemic as observance, violation and easing of the quarantine regulations; creation of a strategy of public behavior aimed at containing the pandemic growth; growth of mood of panic and conspiracy theories; and the stigmatization of patients with coronavirus. This layer of everyday and colloquial medical vocabulary is considered from the standpoint of semantic, stylistic, linguopragmatic and axiological analysis, revealing the pragmatic potential of new words and expressions reflecting the pandemic impact on public consciousness. In particular, the humorous, ironic, satirical plans of this new medical vocabulary are considered, serving the purpose of creating a new value system aimed at overcoming the consequences of the pandemic through psychological compensation. The links between nonprofessional medical and political discourses are also identified, reflecting the extreme politicization of modern media, which affects the reality perception by common participants in the discourse. The combination of these vocabulary items provides a comprehensive picture of the specifics of public life in mass psychology during the spread of the coronavirus pandemic. The study material is the articles of the Urban Dictionary online dictionary of Internet slang devoted to various aspects of the coronavirus pandemic impact on public and private life. Based on the analysis of this constantly updated material, we deduce the regularities of the attitude evolution towards the coronavirus pandemic of a significant part of the international community.
\end{abstract}

Keywords: social and psychological consequences of the coronavirus pandemic, neologisms, non-

professional medical discourse, everyday and colloquial medical vocabulary, humor, coping behavior,

transformation of public consciousness

\section{INTRODUCTION}

The continuous spread of the coronavirus pandemic has led to significant social and psychological consequences, which are reflected in the new vocabulary of nonprofessional English language medical discourse. The consequences of the pandemic (medical system crisis, quarantine regulation introduction, global world order disruption, economic collapse, spread of panic, emergence of conspiracy theories, stigmatization of coronavirus patients affected most of the world population. The collective consciousness could not but reflect the consequences of catastrophic events. Witnesses to the disease spread have created a new lexical layer - everyday and colloquial medical vocabulary dedicated to the results of the coronavirus pandemic. These neologisms are the most vivid reflection of the continuous process of generating new vocabulary by the collective consciousness, which is trying to overcome the catastrophic consequences of the pandemic by categorizing them, creating a system of colloquialisms and expressions that has a hierarchical structure. This vocabulary is most fully represented by the articles of the Urban Dictionary [18], which is a precursor of modern mass culture generated directly by the linguistic activity of common Internet users. The new words and expressions displayed in the Urban Dictionary articles reflect a wide range of situations and opinions generated by a crisis situation. The analysis of this lexical layer allows revealing the specificity of the transformation of collective consciousness during the pandemic. Consideration of the psycholinguistic peculiarities of the lexemes devoted to the social and psychological consequences of a pandemic 
leads to singling out the attitude of collective supranational consciousness towards the disease itself, the people behavior, and the public institutions work during a crisis situation. Studying this segment of everyday and colloquial medical vocabulary provides a comprehensive vision of the mechanisms of resistance of collective consciousness to the pandemic - knowledge that is important not only for linguistic research but also for social psychology and anthropology.

We have considered individual social and psychological consequences of the coronavirus pandemic before [5], but in this study the findings are to a large extent supplemented by diachronic, not only synchronous, conclusions. The possibility of using diachronic analysis was due to the increasing time distance between the appearance of words and expressions reflecting the different stages of recovery from the pandemic. Thus, the real phase of our study of coronavirus pandemics is related to the analysis of the evolution of attitudes to the disease and its social consequences. The vocabulary below has not been analyzed before and is being considered for the first time.

\section{RESEARCH METHODS}

The main part of the research methodological procedures was made up of works devoted to the specifics of nonprofessional medical vocabulary. In Russian linguistics, this topic was considered in a number of studies concerning both general mechanisms of everyday and colloquial medical vocabulary functioning and its specific features. The concept of ordinary medical communication was considered by N.D. Golev and N.N. Shpilnaya [3], [7], who contrasted ordinary communication within the medical discourse of professional communication. The researchers defined the specifics of everyday medical communication as the sphere of realization of cognitive and discursive potential of ordinary linguistic medical consciousness, which carriers are both professionals and non-professionals. Among the types of everyday medical discourse, the researchers single out such a category as ordinary non-professional vocabulary, which is a representation of naive medical ideas. S.V. Mayboroda also considered everyday medical discourse as a space for communication of equal status subjects - informal communication of medical professionals among themselves, as well as communication of patients in different extralinguistic contexts [6]. Abramov V.P. and Abramova G.A. analyzed the peculiarities of sociolectal and everyday and colloquial medical vocabulary [1].

The major problem of this article is the use of black humor as a form of coping behavior using new vocabulary. This aspect has been considered by S.A. Khazova [9]. The researcher considered black humor as an adequate in relation to critical situation strategy for coping with stressful situations. The topic of black humor as an important element of the medical vocabulary stylistic plan was studied by a number of scientists. Thus, D.V. Kazakova speaks about the problem of humor in the medical discourse as an independent subject of study, not reducible exclusively to the social function of humor [4]. The researcher identified the peculiarities of the comic elements in the speech of medical discourse participants black humor and funny metaphors and she identified such elements of humorous vocabulary of medical discourse as humorous industry words and vulgarisms. Kazakova D.V. considered the features of informal speech in the medical discourse, defining its humorous potential, the function of which is the representation of the game nature, entertainment, both playing a multiaspectual role. Medical humor has a function of social impact on the communicant. O.A. Barantseva and Yu.I. Ikova consider the humor role in medical discourse - humor acts as a means of relieving stress and overcoming alienation between participants in medical discourse. Humor, including black humor, has a protective function healthcare providers and their patients are protected from the difficulties of fighting the disease by humorous turning over the elements of reality. The dominant functions of medical humor are foolery and disguising, which play a role of psychological protection from the disease consequences [2]. N.L. Shamne and E.V. Shishkina point to the specificity of the popular scientific medical discourse vocabulary, in particular, its metaphorical connotation [11]. Scientists have also considered sociological research as a genre of popular scientific medical discourse [10].

Also, the methodological base included studies dealing directly with the social and psychological consequences of the coronavirus pandemic. Among these materials, we note articles reflecting the impact of the pandemic on the psychological climate of the Earth's population. Thus, the scientists considered the problems caused by quarantine stress conditions [12], [13], [14], [17]. The problem of social stigmatization of coronavirus patients was raised in a number of articles by foreign researchers [15], [16].

The material specificity has determined the main research methods: we use componential, stylistic, axiological, and linguopragmatic analyses to create a comprehensive picture of the reflection of social and psychological consequences of the coronavirus pandemic in the new nonprofessional vocabulary of medical discourse, supplementing the results of extralinguistic studies of the coronavirus pandemic impact on the international community.

\section{RESEARCH RESULTS}

We analyzed 100 neologisms about the coronavirus pandemic, which were distributed hierarchically - from the names of the disease to the names of social phenomena somehow connected with the pandemic consequences. The corpus of new words and expressions related to various variants of social and psychological protection from destructive influence of coronavirus spreading on public organism was revealed.

The first category of everyday and colloquial medical vocabulary is the slang name of the disease. The humorous 
nature of non-professional medical vocabulary devoted to coronavirus pandemics is clearly seen when ironic names of the disease are considered. The most striking slang name of coronavirus is the disease compared with the tripper recorded in neologism Corona Clap (The Covid 19 Corona virus of 2020 has caused a lot of commotion, worry and even death. As it is a biological infection, like the more common STD gonnarhea clap found around college campuses and trailer parks, as well as throughout congress, this is an alternative slang name combining old and new - thus, the Corona Clap). A pronounced slang name is a kind of compensation for losses and fears caused by the virus. Black humor here serves as a psychological defense, traditional for medical discourse. It should be noted that in the original dictionary article the tripper is associated with unsanitary conditions typical for many student campuses and trailer parks - thus, the dictionary article has acquired a distinct social dimension. In this vocabulary definition, the irony expresses a critical pathos in relation to the established problems to which the article authors attract readers, taking advantage of the current occasion - the coronavirus pandemics spread. Obviously, this expression was born in a student environment and reflects an ironic perception of the disease by this social category. The public twist also has lexemes, reflecting the catastrophic psychological consequences associated with increased panic. In the Russian Internet segment, panic is called "коронабесие" (originally distributed on the site of the Tsargrad TV channel, reflecting the viewpoint of radical Orthodox activists [8]). Close to "коронабесие" stands its foreign analog Pandemishegoss (madness that's related to the 2020 coronavirus pandemic). This word conveys the atmosphere of panic generated by the spread of the pandemic, defining it as an attack of mass psychosis. It should be noted that the social plan of this lexeme is controversial - in its semantics one can see both inadequate seriousness of the situation neglect of the pandemic threat and adequate criticism of the devastating consequences of panic. This neologism opens up a line of words and phrases that have a direct or veiled condemnatory character. Nominations of people that reflect the typical behavior of certain groups of people are particularly often critical. Thus, the negative connotation has the Maskhole invective (Assholes who don't wear masks publicly during the Coronavirus/COVID 19 Pandemic. Especially common in NYC and usually of a certain perceived privaledge and political party(GOP)). This neologism reflects public attitudes toward quarantine violators who ignore the recommendation to wear masks in public. Thus, this layer of neologisms reflects the social attitudes to isolation during a pandemic.

A slightly different type of marginal behavior during a pandemic is coron-optimistic neologism (When someone thinks they have already been exposed to Covid-19, and thus have antibodies for it, because they had one or more symptoms of the disease between January and March 2020). This disease perception is a self-deception, natural for a certain kind of people trying to overcome their fear of the disease by misrepresenting some of the signs of disease characteristic of most respiratory diseases and the direct symptoms of coronavirus. Thus, this category of people gets rid of maintaining quarantine responsibility through protective fantasies that they have already contracted coronavirus. This kind of destructive optimism is also condemned by society, and is shown to be an inappropriate behavior. Thus, the ironic nomination serves the purposes of public security and is a form of social consciousness expression. The Covid-38 word (A person who has been unlucky enough to contract the covid-19 virus twice Covid-38.) is an example of the specific imagery characteristic of black humor - the number 19 in the the disease name is doubled as a sign that the patient gets coronavirus again. The ironic expression Social distancing zombies (In order to maintain a safe distance from others, people were conditioned to raise their arms in front of them. When everyone shuffled around with their arms raised in front of them, the advised level of social distancing was maintained. In lockdown, only a few social distancing zombies were out and about.) denotes those quarantined people whose comical appearance has caused associations with the well-known pop-culture image of zombies. An ironic connotation has the Coronabod neologism (A pasty, doughy body resulting from anxiety eating and inactivity related to the new coronavirus), describing the stay in quarantine as degradation. The exact opposite of the behavior types discussed above is the phenomenon of antisocial nearing (The opposite of social distancing. In a pandemic when people ignore the advice of social distancing and instead engage in antisocial nearing activities like shaking hands, hugging, and spending time in large crowds). The title of the phenomenon highlights the antisocial nature of the neglect of security measures that is inherent in individuals who ignore the pandemic danger.

Some neologisms reflect the specific behavior of pupils, who perceive the introduced protection of the population as an excuse for entertainment. Among them, we highlight the Coronaviruseando neologism (or in English, coronavirusing) (the act of pretending that the coronavirus school break is just an extended spring break (continuing to go to the beach, drinking, etc). This neologism definition is condemnatory, as it contributes to the loss of control and the of pandemic spread. Close in hand is the Coronacation neologism (The time where many students party and enjoy their time away from school because of the coronavirus pandemic), which reflects the behavior of many students during a pandemic.

A separate part of the vocabulary dedicated to coronavirus was the Corona Time joking expressions (The phrase you use when someone near you coughs, often as a joke saying they're going to spread the coronavirus) and Go corona corona go (A very powerful curse words that will stop the spread of coronavirus). The ironic acronym BCAC (BCAC stands for Before Corona Virus and After Corona Virus. This refers to December 31, 2019, which was the first recorded day of Corona Virus) becomes the point of the divide between the two eras - before and after the pandemic outbreak. Such humorous expressions become a form of psychological defense against the panic generated by the pandemic. 
The attempt to adapt the old realities to new circumstances has also led to the creation of words. In this series we highlight the Coronatini neologism (Just like a regular martini but you drink it during a Coronavirus Pandemic or Coronavirus quarantine). This word is formed by blending ("corona "+"martini"). In this neologism, the interpenetration of culinary and medical discourses is evident. The word is at the junction of two lexical categories - names of diseases and names of alcoholic beverages. Contamination of deliberately dissimilar objects gives this word a humorous tinge, conveying the specifics of the pandemic era - the adaptation of familiar things to the changing due to the coronavirus infection spread of life circumstances. This expression gives habitual mundane actions (drinking alcoholic beverages) some romanticism - one of the protective reactions of the psyche to the changing conditions of existence.

The pandemic negative consequence was an increase in distrust and violence. Stigmatization of patients with coronavirus generated a social phenomenon such as Corohara (short for "coronavirus harassment") - the bullying of people who have recently returned from abroad, or who cough in public places.) This neologism has a veiled negative connotation - the bullying of people with coronavirus is associated with the current harassment issue in recent years. (Discrimination against patients with coronavirus has become international [15], [16]). Coronomics (A special brand of pandemic denial that promotes economic status over health and the preservation of life) is one denial form of the importance of precautions during a pandemic. Those who hold this view of the epidemic place economic growth above the health and safety of the majority. These neologisms are condemnatory in nature; their axiological significance is to condemn socially unacceptable behavior.

Corona corridor neologism (an area where people are allowed to travel through to reach a particular destination as the covid-19 lockdown measures are gradually eased) reflected the gradual easing of state measures to combat coronavirus infection. Another easing was the so-called social bubble (a small group of family and friends who are allowed to see each other as the covid-19 lockdown measures are gradually eased). The easing of restrictions was associated with both a gradual decline in the disease growth and social causes - a decline in the life quality of quarantined people [12], [13], [14], [17]. This strategy of easing restrictions has reduced stress and other side effects of self-isolation. The general process of easing restrictions imposed due to coronavirus spread was reflected in the ironic metaphor of covexit (the process of easing the restrictions on public life imposed by the covid-19 pandemic). This word was formed by blending ("coronavirus" + "exit") and is a humorous reference to Brexit (British withdrawal from the EU). This lexeme stands in the same series of ironic transformations of the original word as Mexit (Neologism that emerged after Prince Harry and his wife Megan Markle announced their departure from the official British Royal Family). In this neologism, the function of humor as a protective mechanism again manifested itself - the easing of restrictions caused an ironic reaction of the collective consciousness, expressed in the word-making.

\section{DISCUSSION OF FINDINGS}

New words and expressions related to the coronavirus pandemic can be divided into a number of categories depending on their specifics. We identify the following interrelated groups of neologisms:

- $\quad$ ironic nominations for coronavirus;

- $\quad$ types of socially unacceptable behavior;

- vocabulary of predominantly humorous nature;

- everyday vocabulary that reflects the realities related to the pandemic;

- names of social measures aimed at overcoming the pandemic consequences;

- $\quad$ vocabulary with veiled political overtones.

Most of the considered neologisms correspond to the main parameters of the common everyday medical vocabulary: they are created by ordinary participants in nonprofessional medical discourse and are mostly humorous or ironic in nature. Appealing to humor and irony, in this case, is a protective reaction of the collective consciousness to the pandemic threat. The combination of lexical items from these groups creates a comprehensive picture of the public struggle against the consequences of the disease spread. Stylistic analysis reveals the contradictions of the collective consciousness's perception of a pandemic - ironic connotations have both neologisms reflecting ignorance of the pandemic threat and words describing quarantine compliance as absurd conformism. It may also be noted that a look at the vocabulary reveals the difference in attitude toward pandemics between different age and social groups. Thus, neologisms related to the behavior of pupils and students show that representatives of this social and age category are treated less strictly than other participants in the discourse. Actually humorous neologisms reflect both the hope of overcoming the pandemic, and the mood characteristic of the post-irony era - drawing attention to catastrophic problems by masking them under a purely ironic vocabulary. Everyday lexemes reflect the desire to organize comfortable living conditions during the period of disruption of habitual social connections, which led to physical and moral discomfort. Neologisms, which reflected the negative attitude of a part of society towards the individuals infected with coronavirus, reflect the lack of public consensus on the consequences of the pandemic and reveal such an urgent problem as social discrimination of individuals stigmatized by the disease. The most relevant part of the new vocabulary related to coronavirus is the names of social measures to correct the negative consequences of quarantine. Thus, this segment of the new 
vocabulary shows not only the very process of fighting the pandemic, but also foreshadows its final result, which is continuously sought by the collective humanity consciousness. Neologisms of a political nature reflect the maximum politicization of social thinking, typical for an era of general crisis of social identity. Thus, the vocabulary devoted to the coronavirus pandemic reflects a broad cross-section of acute social problems of our time and their result is a radical transformation of public consciousness. We assume that online dictionary articles reflecting informal medical vocabulary are a form of nonprofessional sociological observation, the analysis of which is necessary to create a comprehensive sociological picture of the impact of the coronavirus pandemic on public life.

\section{CONCLUSION}

Neologisms of non-professional medical discourse, devoted to social and psychological consequences of coronavirus pandemic, fully reflected the functioning of mass consciousness in the period of catastrophic social changes. The phenomena range shown varies from ironic names of the disease itself to figurative lexemes reflecting state strategies to overcome the destructive impact of the pandemic on society. Thus, the sample of neologisms considered by us has become an adequate reflection of the process of overcoming the pandemic consequences - the importance of this aspect is emphasized by a direct correlation of the results of linguistic and social and psychological research. The specific feature of this lexical layer was the humorous nature, which is a form of coping behavior in unpredictable situations caused by the growth of coronavirus morbidity. The establishment of socially acceptable behavior during the pandemic determined the axiological plan for this segment of non-professional medical vocabulary. Diahronic analysis of neologisms associated with coronavirus revealed the nature of gradual weakening of the pandemic impact on social relations and psychological climate of representatives of collective consciousness, thus confirming the effectiveness of constructive strategies of public resistance to the pandemic.

\section{ACKNOWLEDGMENT}

The research was carried out with the financial support of the Russian Foundation for Basic Research (Department of Humanities and Social Sciences) within the framework of scientific project No. 20-012-00033 "Linguistic Models of Social and Political Communication in the Online Space: Discursive Fields, Patterns and Hybrid Methodology of Network Data Analysis" (2020-2022, research advisor is V.V. Katermina).
The main discovery of the study is the fact that the vocabulary devoted to the pandemic is evolving, reflecting the following stages of mass perception of the spread disease - the initial panic, the emergence of an effective strategy of resistance to the pandemic and the creation of a new system of values aimed at protecting society, reducing panic and humorous reflection on what is happening, weakening of state bans as a result of the effectiveness of quarantine measures. Thus, the evolution of the attitude towards the coronavirus pandemic has its own sequence, becoming a gradual weakening of panic and negativistic sentiments, which are replaced by a balanced assessment of what is happening.

\section{REFERENCES}

[1] V.P. Abramov, G.A. Abramova. Sotsiolektnaya i obikhodno-prostorechnaya meditsinskaya leksika. M., Krasnodar: 2003.

[2] O.A. Barantseva, YU.I Ikova. Yumor v meditsinskom diskurse // Problemy romanogermanskoy filologii, pedagogiki i metodiki prepodavaniya inostrannykh yazykov. 2014. № 10. S. $11-15$.

[3] N.D Golev, N.N Shpil'naya. Obydennaya meditsinskaya kommunikatsiya (vidy diskursivnykh praktik) // Vestnik Kemerovskogo gosudarstvennogo universiteta. 2012. № 1 (49). S. 128-137.

[4] D.V Kazakova. Kategoriya komicheskogo v meditsinskom diskurse: dis. ... kand. filol. nauk. Kemerovo, 2013. $312 \mathrm{~s}$.

[5] V.V Katermina, S.Ch. Lipiridi. Osobennosti otobrazheniya pandemii koronavirusa v leksike meditsinskogo diskursa (na osnove angliyskikh neologizmov). Izvestiya Volgogradskogo gosudarstvennogo pedagogicheskogo universiteta. 2020. № 4 (147). S. 170-175.

[6] S.V. Mayboroda. Meditsinskiy diskurs: sovremennyye teoretiko-metodologicheskiye podkhody i perspektivy issledovaniya. // Kommunikativnyye issledovaniya. 2017. № 1 (11). S. 63-74.

[7] M.S. Nevzorova. Kommunikativnoye povedeniye ravnostatusnykh sub"yektov meditsinskogo diskursa (na materiale angliyskogo yazyka): dis. ... kand. filol. nauk. Volgograd, 2017. 203 s.

[8] M. Tyurenkov. Koronabesiye Fanara: Konstantinopol'skiy patriarkhat reshil ostavit' pravoslavnykh bez bogosluzheniy // Sayt telekanala «Tsar'grad» [Elektronnyy resurs]. URL: 
https://tsargrad.tv/articles/koronabesie-fanarakonstantinopolskij-patriarhat-reshil-ostavitpravoslavnyh-bez bogosluzhenij_243928 (data obrashcheniya: 07.08.2020)

[9] S.A. Khazova. Yumor kak resurs sovladayushchego povedeniya // Sibirskiy pedagogicheskiy zhurnal. 2017. № 3. S. 177-182.

[10] N.L. Shamne, Ye.V. Shishkina. Nauchnopopulyarnyye meditsinskiye internet-izdaniya na nemetskom yazyke: strukturnyy i funktsional'nyy aspekty // Vestnik Volgogradskogo gosudarstvennogo universiteta. Seriya 2. YAzykoznaniye. 2017. T. 16, № 2. S. $143-151$.

[11] N.L. Shamne, Ye.V. Shishkina. Osobennosti leksicheskogo sostava meditsinskogo nauchnopopulyarnogo diskursa (na materiale nemetskoyazychnykh internet-izdaniy) // Vestnik Volgogradskogo gosudarstvennogo universiteta. Seriya 2, YAzykoznaniye. 2018. T. 17, № 4. S. 170-179.

[12] S.K. Brooks, R.K. Webster, L.E. Smith, L. Woodlan, S. Wessely, N. Greenberg, G. J. Rubin. The psychological impact of quarantine and how to reduce it: rapid review of the evidence. In: The Lancet 395 (2020) 912-920. Published: February 26, 2020. DOI:https://doi.org/10.1016/S0140-6736(20)30460-8

[13] K. Courtenay, B. Perera. COVID-19 and people with intellectual disability: impacts of a pandemic. In: Irish Journal of Psychological Medicine. Published online by Cambridge University Press: 14 May 2020. DOI: https://doi.org/10.1017/ipm.2020.45

[14] C. Mazza, E. Ricci, S. Biondi, M. Colasanti, S. Ferracuti, Ch. Napoli, P. Roma. A Nationwide Survey of Psychological Distress among Italian People during the COVID-19 Pandemic: Immediate Psychological Responses and Associated Factors. Int. J. Environ. In: Res. Public Health 2020, 17(9) (2020) 3165 DOI: https://doi.org/10.3390/ijerph17093165

[15] S. Swapnajeet, M. Aseem, S. Vikas, M. Pankaj, N.Y. Lakshmi, D.P. Goverdhan, G. Sandeep. Lived experiences of the corona survivors (patients admitted in COVID wards): A narrative real-life documented summaries of internalized guilt, shame, stigma, anger. In: Asian J Psychiatr. Published online 2020 May 30. DOI: 10.1016/j.ajp.2020.102187

[16] G. Sotgiu, G. Carta, L. Suelzu, D. Carta, G. Migliori. How to demystify COVID-19 and reduce social stigma. In: The International Journal of
Tuberculosis and Lung Disease, Vol. 24 (6) (2020) 640642. DOI: $10.5588 /$ ijtld.20.0233

[17] V. Volpert, M. Banerjee, A. d'Onofrio, T. Lipniacki, S. Petrovskii, Viet Chi Tran. Coronavirus: Scientific insights and societal aspects. In: Math. Model. Nat. Phenom. Vol. 15 (2020) DOI: https://doi.org/10.1051/mmnp/2020010

[18] Urban Dictionary [Elektronnyy resurs]. URL: http://www.urbandictionary.com/ (data obrashcheniya: 07.08.2020) 